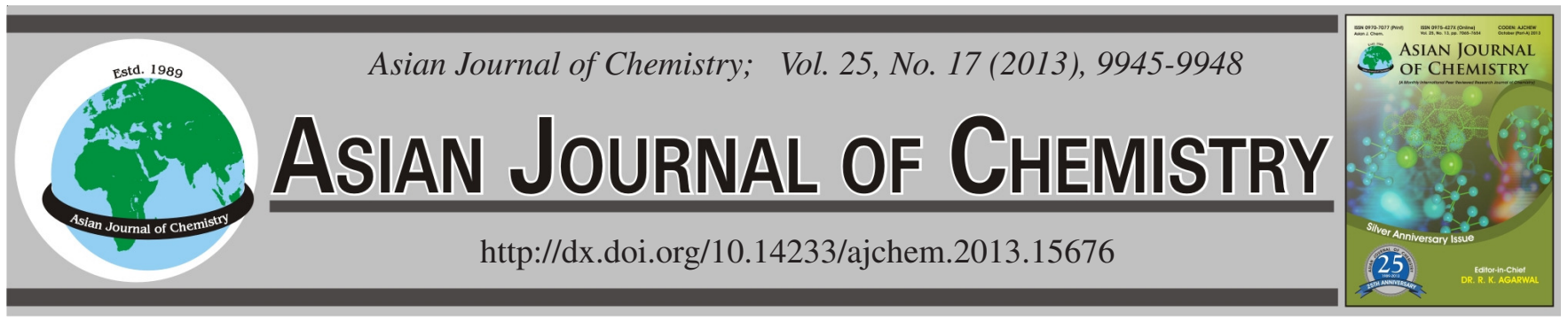

\title{
Phytochemical Evaluation and Bioactive Properties of Different Parts of Cassia occidentalis Plant Extracts
}

Irshad Ahmad, Kamran Bashir, Imran Shair Mohammad*, Muhammad Wajid and Muhammad Majid Aziz

Department of Pharmacy, The Islamia University of Bahawalpur, Bahawalpur, Pakistan

*Corresponding author: Tel: +92 3458012087; E-mail: imranshairmohammad@gmail.com

(Received: 23 April 2013;

Accepted: 29 October 2013)

AJC-14311

The aim of this study is to investigate the secondary metabolites (bioactive constituents), antioxidant and enzyme inhibitory activities of
the dichloromethane and methanolic extract of roots and aerial parts of the plant Cassia occidentalis which belongs to the family leguminosae.
The extraction of coarse powder of dried roots and aerial parts of plant material was performed with dichloromethane and successively
with methanol at room temperature. The filtrate was concentrated on rotary evaporator at $35^{\circ} \mathrm{C}$. Then different phytochemical tests were |
performed for the identification of secondary metabolites, which revealed the presence of saponins, flavonoids, tannins, resins, |
anthraquinones and cardiac glycosides. The dichloromethane and methanolic extracts of Cassia occidentalis have bioactive secondary
metabolites, significant free radical scavenging (antioxidant) and enzyme inhibitory activities such as chymotrypsin and lipoxygenase.

Key Words: Secondary metabolites, Dichloromethane and methanolic extracts, Chymotrypsin and lipoxygenase enzyme inhibition. |

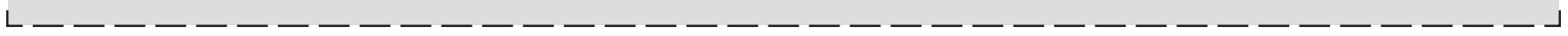

\section{INTRODUCTION}

Cassia occidentalis is an annual herb commonly known as Senna occidentalis belongs to genus Cassia family leguminosae. Its vernacular names are Kasondi, Kasmard and Coffee senna. It is usually an erect plant but also a little bit branched, smooth, semi-woody, fetid herb or shrub. It varies in length from 0.8 to $1.5 \mathrm{~m}$. Therapeutically it was used for sore eyes, constipation, fever, cancer and venereal diseases ${ }^{1}$. Different pharmacological activities like antimicrobial activity have been reported from different parts of the plant like leaves, seeds and roots ${ }^{2,3}$. The leaves of this plant have hepatoprotective effect ${ }^{4}$, anticancer effect ${ }^{5}$, antimalarial effect ${ }^{6}$, antioxidant effect ${ }^{7}$, antiinflammatory effect ${ }^{8,9}$ and a potent antidiabetic, laxative and anthelmentic agent ${ }^{10-12}$. Plants synthesize a variety of bioactive metabolites that have been studied to some extent. The physiology and biochemistry of secondary metabolism gives an opportunity to breed plants with a better protection against microbes. Understanding of their molecular pharmacology is a key to exploit bioactive plant chemicals in a rational way in medicine and agriculture (biorational pesticides). Some natural products are also involved in defense against a-biotic stress, e.g. UV-B exposure. Many of the secondary metabolites have interesting biological properties and a number are of medicinal importance. Because the production of the valuable natural products, such as benzylisoquinoline, monoterpene indole and diterpene alkaloids ${ }^{13}$.<smiles>O=c1c(O)c(-c2ccc(O)c(O)c2)oc2cc(O)cc(O)c12</smiles><smiles>O=c1c(O)c(-c2ccc(O)cc2)oc2cc(O)cc(O)c12</smiles>

Chemical structures of quercetin and kaempferol

Oxygen is an indication of life. It produces energy by oxidation of the food. The oxidation of food produces energy and free radicals which can be harmful for the body. These free radicals may cause degenerative issues like skin depigmentation and aging as well as chronic disorders like atherosclerosis, cancer and diabetes. Antioxidants are the chemical compounds that delay or inhibit oxidative damage to a target 
molecule. Antioxidants avoid cellular and tissue injury by acting as free radical scavengers. They can produce protective effects by neutralizing free radicals, which are responsible for a number of diseases i.e. cancer, aging, heart and gastric problems ${ }^{14}$. Antioxidants are now recommended as daily dietary component because of their importance for the maintenance of health and in protecting the damage due to oxidative stress. There is little toxicity observed due to the use of synthetic antioxidants, so now a day there is increase in use of natural antioxidants.

Enzymes are usually made up of proteins that are helpful in catalyzing chemical reactions. Enzymes increase the rate of reactions until they acquire the equilibrium, although they do not alter thermodynamic properties of the reaction. Chymotrypsin is a digestive proteolytic enzyme belongs to the family of chymotrypsin type serine proteinases. Some of the plants contain some proteins or peptides that can inhibit the activity of chymotrypsin and plants need these specific proteins to protect it against insects and regulation of endogenous proteases ${ }^{15,16}$. Plant derived proteinase inhibitors that are active towards proteases that regulate human physiological processes, e.g. cell signaling/migration, digestion, fertilization, growth, differentiation, immunological defense, wound healing and apoptosis ${ }^{17}$. Lipoxygenase is an enzyme responsible for catalyzing the process of dioxygenation of polyunsaturated fatty acids in lipids. They breakdown arachidonic acid into leukotrienes ${ }^{18}$ which are used in a variety of diseases such as atherosclerosis, cancer, asthma, osteoporosis and chronic obstructive pulmonary disease $\mathrm{e}^{19,20}$.

\section{EXPERIMENTAL}

The plant material (roots and aerial parts) were collected from the local area of District Bahawalpur and District Lodhran, Punjab, (Pakistan) in the month of February and was authenticated as Cassia occidentalis. by the Prof. (Dr.) Altaf Ahmad Dasti, Institute of Applied and pure Biology; Bahauddin Zakariya University Multan. Reference number is 159. The roots and aerial parts of the plant were placed in the herbarium at the Islamia University of Bahawalpur, Bahawalpur, Pakistan for future reference and its voucher number is 172 .

Extraction: The aerial and root parts of Cassia occidentalis were separated and shade dried. Then extraction of coarse powder of dried plant material was performed with dichloromethane and successively with methanol at room temperature. The filtrate was concentrated on rotavapor at $35^{\circ} \mathrm{C}$.

Phytochemical screening: The different chemical tests were performed on the extracts of roots and aerial parts of Cassia occidentalis to screen for various classes of bioactive secondary metabolites such as alkaloids, saponins, tannins, flavonoids, cardiac glycosides and anthraquinones according to the methods described by El-Olemy and co-workers ${ }^{21}$ and Trease and Evans ${ }^{22}$.

DPPH radical scavenging activity: The constant 1,1diphenyl-2-picrylhydrazyl radical (DPPH) was used for the determination of antioxidant activity. A range of concentrations of compounds in relevant solvents were added at an equal volume $(10 \mu \mathrm{L})$ to $90 \mu \mathrm{L}$ of methanolic DPPH $(100 \mu \mathrm{M})$ in a total volume of $100 \mu \mathrm{L}$ in 96 -well plates. The contents were mixed and incubated for $0.5 \mathrm{~h}$. The absorbance measured at $517 \mathrm{~nm}$. The standard antioxidants, quercetin were used. The experiments were accomplished in triplicates. (EZ-Fit 5 Perrella Scientific Inc). The decrease in absorbance means the increase in radical scavenging activity which was calculated by the given formula.

Per cent scavenging activity $=[100-($ Abs. of test compounds/Abs. of control) $\times 100]^{23}$

Chymotrypsin assay: The chymotrypsin inhibition activity is performed according to slightly modified method of Rahman et al. $^{24}$. A total volume of $100 \mu \mathrm{L}$ assay mixture contained $60 \mu \mathrm{L}$ Tris- $\mathrm{HCl}$ buffer $(50 \mathrm{mM} \mathrm{pH} \mathrm{7.6),} 10 \mu \mathrm{L}$ test compound and $15 \mu \mathrm{L}$ ( 0.9 units) purified chymotrypsin enzyme (Sigma, USA). The contents were mixed and incubated for $20 \mathrm{~min}$ at $37^{\circ} \mathrm{C}$ and pre-read at $410 \mathrm{~nm}$. The reaction was initiated by the addition of $15 \mu \mathrm{L}(1.3 \mathrm{mM})$ substrate ( $\mathrm{N}$-succinyl phenyl-alanine- $p$-nitroanilide). The change in absorbance was observed after $0.5 \mathrm{~h}$ at $410 \mathrm{~nm}$. Synergy HT (Biotech, USA) 96-well plate reader was used in all experiment. All reactions were performed in triplicates. The positive and negative controls were included in the assay. Chymostatin $(0.5 \mathrm{mM}$ well) was used as a positive control. The percentage inhibition was calculated by formula given below.

$$
\text { Inhibition }(\%)=\frac{\text { Control }- \text { Test }}{\text { Control }} \times 100
$$

where, Control $=$ Total enzyme activity without inhibitor; Test $=$ Activity in the presence of test compound.

$\mathrm{IC}_{50}$ values were calculated using EZ-Fit Enzyme Kinetics Software (Perrella Scientific Inc. Amherst, USA).

Lipoxygenase assay: Lipoxygenase (LOX) activity was assayed according to the method of Tappe ${ }^{25}$, Baylac and Racine $^{26}$ with slight modifications. A total volume of $200 \mu \mathrm{L}$ lipoxygenase assay mixture contained $140 \mu \mathrm{L}$ sodium phosphate buffers (100 mM, pH 8.0), $20 \mu \mathrm{L}$ test compound and 15 $\mu \mathrm{L}$ purified lipoxygenase enzyme (600 units well ${ }^{-1}$, Sigma Inc, USA.). The contents were mixed and pre-read at $234 \mathrm{~nm}$ and preincubated for $10 \mathrm{~min}$ at $25^{\circ} \mathrm{C}$. The reaction was initiated by addition of $25 \mu \mathrm{L}$ substrate solution. The change in absorbance was observed after $6 \mathrm{~min}$ at $234 \mathrm{~nm}$ using 96-well plate reader Synergy HT, Biotech, USA. All reactions were performed in triplicates. The positive and negative controls were included in the assay. Baicalin $\left(0.5 \mathrm{mM}\right.$ well $\left.{ }^{-1}\right)$ was used as a positive control.

The percentage inhibition (\%) was calculated by the given formula.

$$
\text { Inhibition }(\%)=\frac{\text { Control }- \text { Test }}{\text { Control }} \times 100
$$

where, Control $=$ Total enzyme activity without inhibitor; Test $=$ Activity in the presence of test compound.

\section{RESULTS AND DISCUSSION}

Phytochemical screening of bioactive secondary metabolites: The phytochemical analysis was carried on roots and aerial parts of the plant. The results of screening revealed that these parts of plant are bioactive because they contain secondary metabolites like tannins, flavonoids, saponins, 
anthraquinones and cardiac glycosides. The result of the present study exhibits that the plant contains important secondary metabolites like cardiac glycosides, saponins, flavonoids, anthraquinones and tannins which are responsible for various pharmacological actions like antioxidant, anticancer, antidiabetic, antiinflammatory and hepatoprotective effect. The plant also demonstrated good antioxidant activity and chymotrypsin inhibitory activity which suggests the presence of proteinases inhibitors. So, the plant can found potential therapeutic applications in cancer and hepatitis research. The results are shown in Table-1.

\begin{tabular}{clc}
\multicolumn{4}{c}{ TABLE-1 } \\
\multicolumn{3}{c}{$\begin{array}{c}\text { PHYTOCHEMICAL ANALYSIS OF THE EXTRACTS OF } \\
\text { ROOT AND AERIAL PARTS OF Cassia occidentalis }\end{array}$} \\
\hline Serial No. & Phytochemical tests & Test results \\
\hline 1 & Alkaloids & - \\
2 & Saponins & + \\
3 & Tannins & + \\
4 & Flavonoids & ++ \\
5 & Cardiac glycosides & ++ \\
6 & Anthraquinones & ++ \\
\hline
\end{tabular}

Antioxidant activity: The DPPH radical scavenging assay was performed to determine the antioxidant potential of dichloromethane and methanolic extracts of root and aerial parts of the plant. The decrease in absorbance was determined and results of this assay revealed that amongst all the extracts of the plant showed good antioxidant activity by keeping quercetin as a positive control and results are shown in Table-2. During phytochemical screening the presence of flavonoids were confirmed which are responsible for the antioxidant activity. Flavonoids enhanced the activity of vitamin C, protect LDL cholesterol from oxidation, inhibit platelet aggregation and act as antiinflammatory and antitumor agent.

\begin{tabular}{cccc} 
TABLE-2 & $\begin{array}{c}\text { ANTIOXIDANT ACTIVITY OF DICHLOROMETHANE } \\
\text { AND METHANOL EXTRACTS OF ROOT AND } \\
\text { AERIAL PARTS OF Cassia occidentalis }\end{array}$ \\
\hline S. No. & Extracts used & Conc. $(\mathrm{mg} / \mathrm{mL})$ & $\begin{array}{c}\text { DPPH } \\
\% \text { inhibition }\end{array}$ \\
\hline 1 & COAD & 0.5 & $53.69 \pm 0.96$ \\
2 & COAM & 0.5 & $61.95 \pm 0.87$ \\
3 & CORD & 0.5 & $48.83 \pm 0.45$ \\
4 & CORM & 0.5 & $55.43 \pm 0.28$ \\
5 & Quercetin & 0.5 & $92.17 \pm 0.90$ \\
\hline COAD = Cassia occidentalis aerial extract dichloromethane. \\
COAM = Cassia occidentalis aerial extract methanol. \\
CORD = Cassia occidentalis roots extract dichloromethane. \\
CORD = Cassia occidentalis roots extract methanol.
\end{tabular}

Enzyme inhibitory activity: The chymotrypsin enzyme inhibitory activity was performed by using chymostatin as a standard. The relative percent enzyme inhibition along with $\mathrm{IC}_{50}$ of all the extracts and standard were analyzed. All extracts of the plant have significant chymotrypsin enzyme inhibitory activity as given in Table-3. Epidemiological studies demonstrating a decrease in occurrence of breast, colon and prostatic cancers in vegetarian populations has suggested the role of plant proteinase inhibitors in preventing these cancers. A

\begin{tabular}{ccccc}
\hline \multicolumn{5}{c}{ TABLE-3 } \\
\multicolumn{5}{c}{ CHYMOTRYPSIN ENZYME INHIBITION ACTIVITY OF } \\
DICHLOROMETHANE AND METHANOLIC EXTRACTS \\
OF ROOT AND AERIAL PARTS OF Cassia occidentalis \\
\hline S. & Extracts used & Conc. & Inhibition & $\mathrm{IC}_{50}(\mu \mathrm{g} / \mathrm{L})$ \\
No. & COAD & 0.5 & $69.48 \pm 0.22$ & $364.5 \pm 0.81$ \\
\hline 1 & COAM & 0.5 & $65.45 \pm 0.18$ & $355.9 \pm 0.83$ \\
2 & CORD & 0.5 & $66.49 \pm 0.09$ & $350.5 \pm 0.93$ \\
3 & CORM & 0.5 & $81.04 \pm 0.19$ & $140.8 \pm 0.60$ \\
4 & Chymostatin & 0.5 & $93.50 \pm 0.91$ & $8.24 \pm 0.11$ \\
5 & COAD = Cassia occidentalis aerial extract dichloromethane. \\
\hline COAM = Cassia occidentalis aerial extract methanol. \\
CORD = Cassia occidentalis roots extract dichloromethane. \\
CORD = Cassia occidentalis roots extract methanol.
\end{tabular}

soybean-derived Bowman-Birk protease inhibitor (BBI) either inhibits or prevents development of experimentally induced colon, oral, lung, liver and esophageal cancers ${ }^{26}$. This anti carcinogenic effect of the Bowman-Birk protease inhibitor is thought to stem from its ability to inhibit chymotrypsin enzyme activity. The lipoxygenase enzyme inhibitory activity was conducted by using baicalin as positive control. The percentage of enzyme inhibition of all the extracts were measured and all the extracts of the plant have shown significant lipoxygenase enzyme inhibition which are shown in Table-4. Lipoxygenase inhibitors play a vital role as an antiinflammatory agent but their prolonged and extensive use causing several side effects so there is need to identify some natural sources of lipoxygenase enzyme inhibition.

TABLE-4

LIPOXYGENASE ENZYME INHIBITORY ACTIVITY OF DICHLOROMETHANE AND METHANOLIC EXTRACTS OF ROOTS AND AERIAL PARTS OF Cassia occidentalis

\begin{tabular}{cccc}
\hline S. No & Extracts used & Conc. $(\mathrm{mg} / \mathrm{mL})$ & LOX inhibition $(\%)$ \\
\hline 1 & COAD & 0.5 & $60.75 \pm 0.96$ \\
2 & COAM & 0.5 & $55.79 \pm 0.67$ \\
3 & CORD & 0.5 & $51.62 \pm 0.73$ \\
4 & CORM & 0.5 & $65.17 \pm 0.75$ \\
5 & Baicalin & 0.5 & $93.79 \pm 1.27$ \\
\hline
\end{tabular}

$\mathrm{COAD}=$ Cassia occidentalis aerial extract dichloromethane.

$\mathrm{COAM}=$ Cassia occidentalis aerial extract methanol.

$\mathrm{CORD}=$ Cassia occidentalis roots extract dichloromethane .

$\mathrm{CORD}=$ Cassia occidentalis roots extract methanol.

\section{ACKNOWLEDGEMENTS}

The authors thank the Chairman of the Department of Pharmacy, The Islamia University of Bahawalpur for allowing this research work.

\section{REFERENCES}

1. J.P. Yadav, V. Arya, S. Yadav, M. Panghal, S. Kumar and S. Dhankhar, Fitoterapia, 81, 223 (2010)

2. S. Kumar, S. Dhankhar, V. Arya, S. Yadav and J.P. Yadav, Res. J. Med. Plants, 6, 2754 (2012).

3. M. Mohammed, M.A. Aboki, H.M. Saidu, O. Victor, A. Tawakalitu and S.A. Maikano, Int. J. Sci. Technol., 2, 200 (2012).

4. M.A. Jafri, M.J. Subhani, K. Javed and J. Singh, J. Ethanopharmacol., 66, 355 (1999).

5. B.B. Hafeez, I. Ahmad, R. Hauqe and S. Rasiuddin, J. Ethnopharmacol., 7, 13 (2001).

6. L. Tona, K. Mesia, N.P. Ngimbi and K. Cimanga, Ann. Trop. Med. Parasitol., 95, 47 (2001). 
7. G.P. Vadnere, A.V. Patil, S.K. Jain and S.S. Wagh, Int. J. Pharm. Res., 3, 1985 (2011)

8. J. Sadique, T. Chandra, V. Thenmozhi and V. Elango, J. Ethanopharmacol., 19, 201 (1987).

9. M. Sheeba, S. Emmaneul, K. Revathi and S. Ignacimuthu, Int. J. Integ. Biol., 8, 1 (2009)

10. M.M. Onakpa and O.P. Ajagbonna, Int. J. Pharm. Res., 4, 1766 (2012).

11. A.A. Elujoba, A.T. Abere and S.A. Adelusi, Nig. J. Nat. Prod. Med., 3, 51 (1999).

12. M.A. Ibrahim, N. Nwude, R.A. Ogunsusi and Y.O. Aliu, 5th Int. Symposium on Medicinal Plants Uni of Ife-Ile-Ife Nigeria (1983).

13. H. Schafer and M. Wink, Biotechnol. J., 4, 20 (2009).

14. S. Sen, R. Chakraborty, C. Sridhar and Y. Reddy, Int. J. Pharm. Rev. Res., 3, 91 (2010).

15. V.V. Mosolov, L.I. Grigoreva and T.A. Valueva, Appl. Biochem. Microbiol., 37, 643 (2001).

16. Y. Birk, Plant Protease Inhibitors: Significance in Nutrition, Plant Protection, Cancer Prevention and Genetic Engineering, Springer, pp. 170 (2003).
17. M.K. Abdel-Meguid, in eds.: K. von der Helm, B.D. Korant and J.C. Cheronis, Handbook of Experimental Pharmacology, Springer (2000).

18. P.M. O'Byrne, E. Israel and J.M. Drazen, Ann. Intern. Med., 127, 472 (1997).

19. J.H. Dwyer, H. Allayee, K.M. Dwyer, J. Fan, H. Wu and R. Mar, New Engl. J. Med., 350, 29 (2004).

20. M. Peters-Golden and W.R. Henderson, New Eng. J. Med., 357, 1841 (2007).

21. M.M. El-Olemy. F.J. Al-Muhtadi and A.F.A. Afifi, Experimental Phytochemistry: A Laboratory Manual, King Saud University Press, Saudi Arabia, pp. 21-27 (1994).

22. G.E. Trease and W.C. Evans; Pharmacognosy, Elsevier, Edinburgh, edn 16 (2009).

23. I.I. Koleva, T.A. van Beek, J.P. Linssen, A. de Groot and L.N. Evstatieva, Phytochem. Anal., 13, 8 (2002).

24. A.U. Rahman and M.I. Choudhary, Pure Appl. Chem., 73, 555 (2001).

25. A.L. Tappel, Arch. Biochem. Biophys., 44, 378 (1953).

26. S. Baylac and P. Racine, Int. J. Aromather, 13, 138 (2003).

27. H. Witschi and A.R. Kennedy, Carcinogenesis, 10, 2275 (1987). 